\title{
BASS 4: a software system for ergonomic design and evaluation of working hours
}

\author{
Carsten Schomann ${ }^{\mathrm{a}}$, Wolfgang Stapel ${ }^{\mathrm{a}}$, Peter Nickel ${ }^{\mathrm{a}}$, Jens Eden ${ }^{\mathrm{b}}$ and Friedhelm \\ Nachreiner ${ }^{\mathrm{a}}$
}

${ }^{a}$ Carl von O ssietzky Universität O Idenburg. Department of Psychology. Industrial and O rganisational Psychology U nit. Oldenburg, Germany. 'Informatik. Consulting. Bad Zwischenahn, Germany

\section{Keywords}

Shift work. Work hours. Planning. Workload. Software. Evaluation. Occupational health. Socioeconomic factors.

\section{Descritores}

Trabalho em turnos. Jornada de trabalho. Planejamento. Carga de trabalho. Software. Avaliação. Saúde ocupacional. Fatores

socioeconômicos.

\begin{abstract}
Objective

To extend an existing computer programme for the evaluation and design of shift schedules (BASS 3) by integrating workload as well as economic aspects. Methods

The redesigned prototype BASS 4 includes a new module with a suitable and easily applicable screening method (EBA) for the assessment of the intensity of physical, emotional and cognitive workload components and their temporal patterns. Specified criterion functions based on these ratings allow for an adjustment of shift and rest duration according to the intensity of physical and mental workload. Furthermore, with regard to interactive effects both workload and temporal conditions, e.g. time of day, are taken into account. In a second new module, important economic aspects and criteria have been implemented. Different ergonomic solutions for scheduling problems can now also be evaluated with regard to their economic costs.

Results

The new version of the computer programme (BASS 4) can now simultaneously take into account numerous ergonomic, legal, agreed and economic criteria for the design and evaluation of working hours.

Conclusions

BASS 4 can now be used as an instrument for the design and the evaluation of working hours with regard to legal, ergonomic and economic aspects at the shop floor as well as in administrative (e.g. health and safety inspection) and research problems.
\end{abstract}

\section{Resumo}

\section{Objetivo}

Expandir um programa computacional existente para planejamento e avaliação dos horários de turnos (BASS 3) por meio da incorporação da carga de trabalho e características econômicas.

Métodos

O protótipo BASS 4 contém um novo módulo com um método de triagem (EBA) conveniente e de fácil aplicação para a avaliação da intensidade dos componentes físico, emocional e cognitivo da carga de trabalho e seus padrões temporais. O uso de critérios específicos com base nestas avaliações possibilita ajustar a duração do turno e do descanso de acordo com a intensidade da carga de trabalho física e

\footnotetext{
Correspondence to:

Carsten Schomann

Carl von Ossietzky Universität Oldenburg Institut für Psychologie

Abteilung Arbeits \& Organisationspsychologie

D-26111 Oldenburg, Germany

E-mail: carsten.schomann@uni-oldenburg.de
}

( Financial support: German Federal M inistry for Education and Research of the Federal Republic of G ermany under Contract $01 \mathrm{HW} 0130$

Received on 15/3/2004. Approved on 27/9/2004. 
mental. Além disso, quanto aos efeitos interativos, tanto a carga de trabalho como os aspectos temporais, p. e., hora do dia, são considerados. Foram introduzidos em um outro módulo características e critérios econômicos de relevância. O novo programa permite também que sejam avaliadas diferentes soluções ergonômicas para problemas de planejamento segundo os custos financeiros.

Resultados

A nova versão do programa (BASS 4) tem a capacidade agora de processar simultaneamente vários critérios econômicos, ergonômicos, legais e acordados para o planejamento e avaliação do horário de trabalho.

Conclusões

O BASS 4 pode ser usado agora como um instrumento para planejamento e avaliação dos horários de trabalho, incluindo-se características econômicas, ergonômicas e legais, no setor de produção e em questões administrativas (p.e. fiscalização da saúde e segurança) e relacionados à pesquisa.

\section{INTRODUCTION}

There is a long tradition in ergonomics giving evidence that an ergonomic design of working hours, both with regard to the chronometry (e.g. the duration) and the chronology of working hours (e.g. shift work), as well as to the distribution and pattern of work and rest periods within a certain period of time ${ }^{16,25,26,30}$ is capable of protecting workers against the risk of impairing effects (e.g. fatigue, accidents) and can provide for optimal working conditions in order to promote their health and well-being as well as the reliability and productivity of the work system. ${ }^{24}$ However, since the requirements encountered in the design of working hours, and especially in designing shift schedules, are becoming more and more complex and the claim for an economic optimization of labour is increasing, constructing rotas has become a cumbersome endeavour. Therefore, in order to support those responsible for the design of work schedules at the shop floor a broad range of software tools have been developed. The solutions available are ranging from simple computerized spread sheets for a still manual design of shift schedules to computer aided generation, optimization and evaluation of shift schedules based on workforce requirements and various criteria for the design of working hours. . $^{1522,27,28,42}$ Using computer support in designing acceptable shift schedules - acceptable from a legal, a collectively agreed, and especially from an ergonomics and an organizational perspective - may lead to a number of benefits ${ }^{27,28}$ such as:

a) developing, evaluating and improving shift schedules rather quickly, while effectively taking into account

- legal and collectively agreed requirements

- evidence based ergonomics requirements

- requirements, needs and the experience of workers concerned
- requirements of the company (or employer) or customers

b) allowing for a participative approach in the design of working hours, e.g. by

- demonstrating interdependencies among requirements/ criteria and their effects on the resulting design

- thus enabling informed decisions about design alternatives

- promoting the acceptance of the resulting schedules by those concerned

A concept established in a previously developed computer programme for the design and evaluation of shift schedules, using a stepwise procedure for generating shift schedules (BASS $3^{27,28}$ ), has shown to be suitable for the design of shift schedules for continuous and noncontinuous work with regular or irregular work demands in different areas of application (e.g. public transport, ${ }^{30}$ manufacturing, health care and the services sector ${ }^{17}$ ). In addition to numerous legal, agreed and company specific requirements this programme takes into account ergonomic criteria related to the design of working hours and shift schedules. ${ }^{7,34,43}$ These include more physiologically/ biologically based criteria, e.g. the number of consecutive night shifts, as well as more psychosocially based criteria, e.g. concerning the interaction between working hours and leisure activities. However, according to feedback from small and medium sized enterprises, theoretical reasoning, and some recent research developments several aspects which have not yet been addressed adequately in this programme have been identified, and this seems to hold for computer aided design and evaluation of working time arrangements in general, as can be seen by looking at computer programmes available for this purpose in practice. The present paper will thus address the development of a new programme for which workload and economic aspects have been taken into account in more detail. 
The workload aspect is obviously one of the most important (but obviously also most neglected) factors regarding the ergonomic design and evaluation of working hours, and thus one of the common rules states that, e.g. shift duration should be adapted to the workload, without being more specific, however, as to how this should be done. Although several aspects of workload are involved when taking into account the basic ergonomic criteria mentioned above, the design and evaluation of working hours is still lacking time-related (e.g. circadian rhythms) and jobbased (e.g. work task, work conditions) workload aspects, i.e. the intensity, duration and dynamics of different kinds of workload. This neglect of workload aspects is most probably due to the complexity of the problems involved and the problems of measuring and specifying criterion functions for tolerable or acceptable workload and rest periods with regard to the design of working hours. ${ }^{38}$

Also still missing in the ergonomic computer aided design and evaluation of working hours are economic criteria which support the designer in optimizing schedules, e.g. without negative economic effects such as higher costs. Again feedback from companies identified this as a serious deficiency for BASS 3: while common commercial scheduling programmes show a complete neglect of ergonomic criteria, ergonomic approaches to the scheduling problem have greatly neglected the economic aspects of the problem (for an exception $\operatorname{see}^{15}$ ). Companies wanted to know how much an ergonomically improved design would cost or to be able to estimate the costs associated with different designs. Since a combination of different programmes did not seem promising, an attempt should be made to simultaneously take into account economic criteria and ergonomic criteria in designing as well as in evaluating working hours.

Therefore, in a research and development project supported by the German Federal Ministry for Education and Research under the program 'Innovative work design' an attempt has been made to develop workload and economic criteria/ requirements relevant for the design and evaluation of working hours and to integrate these criteria - along with existing legal, ergonomic and organizational requirements in a software system for a computer aided design, evaluation and optimization of work schedules.

\section{METHODS}

\section{Development and integration of criteria related to workload}

In the context of the design and the evaluation of working hours, the integration of criteria related to workload should include the effects of working conditions (e.g. jobs, tasks, equipment, environment), and of working time arrangements (e.g. constraints related to time on task, time of day) as well as their interactions in order to be able to adequately consider the relevant parameters of workload, i.e. intensity, duration and dynamics, and their interactions. At present, programmes for computer aided design of working hours are mainly able to consider aspects of time-related constraints by taking into account general recommendations (e.g. avoiding extended working days, providing for shorter nightshifts, or a fast forward rotation). ${ }^{15,22,27,28,37,42}$ In general this seems to be a promising strategy since these recommendations are based on empirical evidence, e.g. studies based on national surveys $s^{1,18,25,29}$ or aggregating across different studies ${ }^{12}$ indicating an increase in the accident risk for working hours beyond the normal working day.

Although observing such recommendations have already been shown to be an effective and preventive strategy for reducing the operators' risks of impairments imposed by their working hours, the results must remain insufficient without taking into account information about the nature of the task (e.g. mental or physical), the intensity and the extensity of workload, and their interaction. As has been demonstrated in some studies $2,8,9,11$ there are compensatory processes regarding performance and/or workload during night shifts. In addition, sometimes there are different job demands at night compared to those at day shifts. Considering such aspects factors apart from only time related ones become important. Therefore, some of the limitations of the above mentioned recommendations are due to the fact that the intensity of workload will always depend on the characteristics of the job at hand and therefore the context of application of a certain shift schedule.

Since the context of application serves as the primary source of information which determines the intensity of workload and its relevance for the design of shift schedules, a suitable instrument for the assessment of workload seemed to be necessary, i.e. suitable for practitioners at the shop floor, as they are the people who have to design shift schedules in practice.

There are certain specific requirements for the assessment of workload in the context of the design of working hours and therefore none of the existing instruments in workload assessment could be expected to assess the information required, i.e. the intensity of physical, emotional, and cognitive workload and their dynamics across the working day with a job adequate resolution, e.g. for each hour or quarter of an hour of 
work during each shift in the working day or week, or whatever resolution might be appropriate for the job under consideration. Further requirements would be that such an instrument should be usable for people responsible for the design of working hours in practice, at least at the level of a screening instrument (according to ISO $10075-3^{20}$ ) while at the same time offering a possibility to be integrated into a computer programme for the design of working hours. Such an instrument has not been found; therefore a new and readily tailored instrument had to be developed.

Based on experiences with the evaluation and design of shift schedules in different areas of application and with available (German) instruments for task analysis and the assessment of workload, ${ }^{14,31,33,35}$ core items were collected, pre-selected and adapted according to expert ratings and pre-tested using different video taped work sequences. This led to a first version of a rating scale (EBA, German abbreviation for 'screening of workload at the workplace ${ }^{\text {39-41 }}$ ) with a total of 15 items on physical (6), emotional (4) and cognitive (5) workload components, an instruction how to use EBA and a form for filling in intensity ratings for each item in the appropriate resolution for a time-based assessment.

The suitability of this rating scale for the intended area of application was analysed in a field study in a manufacturing company (In the meantime more analyses in different fields of application have been performed, supporting the evidence gained from this study.). After giving a brief introduction on how to use the EBA rating scales, three ergonomics experts (researchers of the Industrial and Organisational Psychology Unit, Oldenburg) and three job experts (staff from the health, safety and environmental protection department) observed five different jobs (e.g. assembly, inspection) for about 20 minutes each and then filled in the rating scales for each job. This provided information about an integrative, not yet time related, assessment of workload as a first step to determine whether the items would be usable by different groups of raters, especially practitioners, and useful for discriminating between jobs. A time based assessment has been performed in a separate analysis, ${ }^{21}$ comparing the ratings of two observers with psychophysiological recordings taken from workers across complete shifts. Due to space limitations the results of this study cannot be presented here.

Integrating criteria related to workload requires not only the assessment of workload but also a model of how these assessments can be incorporated into the design of shift schedules. Therefore a criterion function had to be specified, taking into account the com- bination of the individual items and dimensions of the intensity of workload from the EBA, combined with the extensity dimensions of workload (i.e. duration, chronological position, sequence of work-rest periods, i.e. the dynamics of workload) for hours at work in a shift schedule..$^{23,36}$ Based on theoretical reasoning derived from basic ergonomic workload concepts ${ }^{19,36}$ the integration of job based (i.e. taken from EBA) and time based workload aspects (e.g. circadian rhythms) has recently been carried out, using conceptual approaches based on results of exploratory analyses of workload

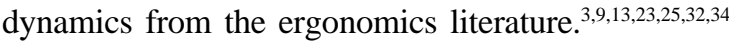
For the development of the criterion function, firstly, EBA ratings for a typical work week in an appropriate resolution were aggregated applying a bottleneck model, i.e. avoiding compensation across the different aspects or items of workload. Secondly, depending on these results an aggregation for time on task was carried out taking into account the multiplicative relation between intensity and duration of workload Thirdly, further aspects of chronology (i.e. time of day) were integrated. Next, a limit for the criterion function was established, with job and time based workload levels beyond this limit being assumed to result in impairments. Finally, the procedure of calculating this criterion function was integrated in BASS 4 and combined with the other criteria for the design and evaluation of working hours.

First results of such an integration of workload criteria into the design and evaluation of shift schedules will be presented.

\section{Integrating economic aspects}

Economic criteria (from business administration) have been identified and specified based on the relevant economic literature ${ }^{6}$ and legal and collectively agreed regulations (e.g. wage agreements), in order to allow for an evaluation and joint optimization of working time systems. The relevant criteria from an economic perspective are the costs of an arrangement of working hours. Based on the economic literature the following types of costs have primarily been considered:

labour costs (to be differentially specified according to professional qualifications)

surcharges (additional labour costs, i.e. costs for work at specified times, e.g. overtime premium, costs for night work (e.g. night work bonus), costs for work on Saturdays or Sundays)

(extra) allowances (i.e. costs across the entire labour time, e.g. productivity pay or shift-worker bonus)

These types of costs, which have to be specified according to the given context, will be applied to the 


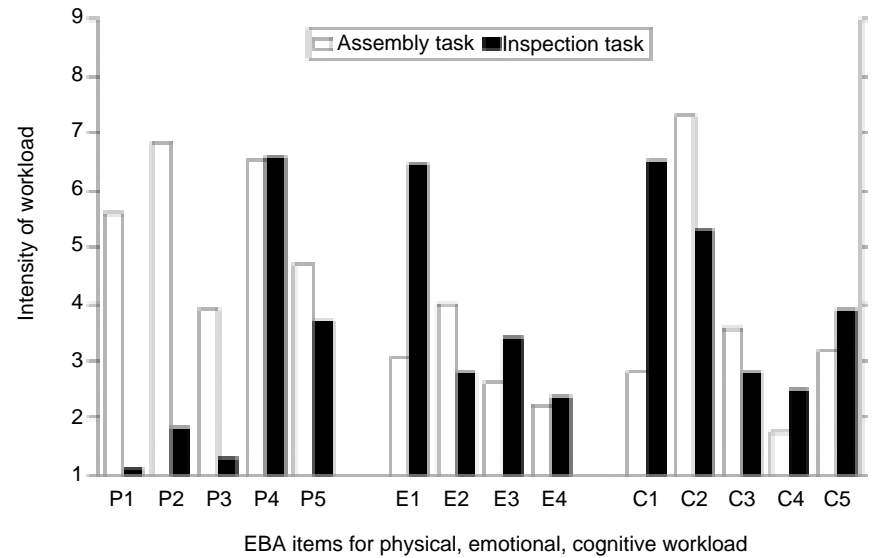

Figure 1 - Results of EBA assessments for different kind of jobs.

ences in using (at least some of) the 15 items between both observer groups. A closer inspection of the results revealed a tendency towards more conservative ratings, i.e. indicating higher levels of workload for static muscular work or demands on information processing for the job experts (practitioners) group, which was most probably due to the practitioners' long time experience with the working conditions at hand. According to the non significant triple interaction (Item by Job by Observer group) there seemed to be no tendency for some experts to systematically rate some items at a different level for some jobs. These results would indicate an acceptable understanding and use of the concepts

economic evaluation of working hours. Different working time arrangements can then be compared based on these costs, as well as on the basis of total costs for each system. For the design and evaluation of work schedules these types of costs have been implemented as cost functions, using a linear optimization approach $^{5}$ (also known as operations research; i.e. maximizing a linear function over a convex polyhedron). In the evaluation of generated or given shift schedules these costs will be considered and presented to the user on different levels of aggregation and in different styles of representation.

\section{RESU LTS}

\section{Development and integration of workload related criteria}

The suitability of the EBA rating as a workload screening instrument was analyzed using a $2 \times 5 \times 15$ analysis of variance with two observer groups ( 3 ergonomics experts, 3 job experts), and five different jobs as between factors, and the 15 items of the EBA as a within factor. GreenhouseGeiser corrections for violations of sphericity (including results for $\varepsilon_{\mathrm{GG}}$ ) ${ }^{44}$ were applied where appropriate.

With regard to possible general differences in the ratings between the two groups of raters and/or the five jobs neither of the main effects nor their interaction were significant. However, the main effect for the Observer group factor was marginally significant, $F(1$, $25)=3.8, p=.063$, indicating that both groups rated - in general - slightly differently. To understand this main effect, the significant interaction for Observer-group by Item, $F(14$, $350)=2.56, \varepsilon_{\mathrm{GG}}=.09, p=.023$, should be taken into account, indicating that there are differ-

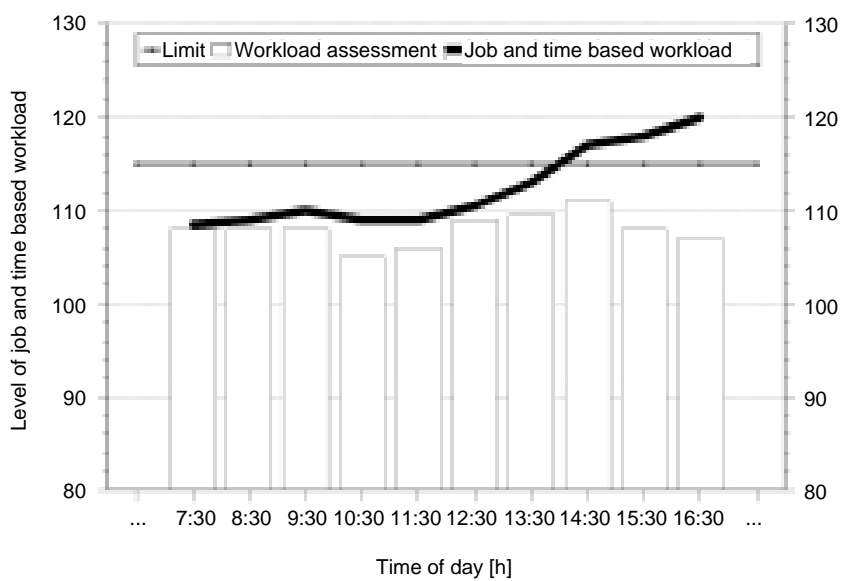

Figure 2 - An example for the concept of a workload criterion function for the design and evaluation of working hours. 
the resulting strain in the worker (resulting from the combination of job and time based workload, their interactions, accumulated for time on task; indicated by the bold line in Figure 2) is assumed to increase, since there is no break and thus no possibility for recuperation.

According to the conceptualized model and the example illustrated in Figure 2, the bold line would indicate that a shift duration of up to 7 hours would be acceptable, since during the $8^{\text {th }}$ hour (and later on) the level of workload (in this case the strain within the worker) is beyond the specified limit (thin line in Figure 2 ). As there is no change in the job based level of workload during the first $3 \mathrm{~h}$ the increase in strain is based on a feedback effect of a non compensated high level of workload over time, i.e. with no break and thus no recuperation, so that the next period (hour) of work will meet a reduced capacity for work, resulting in increased work strain and fatigue. In this case, this has been combined with a time based workload effect, e.g. a post lunch dip, ${ }^{10}$ which decreases working capacity as well.

Based on results like those presented in Figure 2 different interventions for the design of an acceptable shift schedule from a workload perspective would be possible: (1) limiting the duration of the shift to seven hours, (2) reducing the job based level of workload through a reorganization of working conditions, (3) implementing an additional shift group in order to distribute the job based workload to parallel shift groups, and/or (4) providing adequate rest breaks in order to provide for recuperation and thus interruptions of the feedback loop.

So far, relevant components of the criterion function have been identified, concepts for an integration of these components and for the required calculations have been drawn up and checked against theoretical reasoning and results from field studies and have been adapted where appropriate. Lack of space, the provisional nature of these function(s) and their status of being still subjected to further testing do not allow for an extensive treatment here.

The criterion function is now being implemented in the software programme and will soon be available for some first tests regarding the generation and optimization of shifts and shift schedules. In order to validate and improve the criterion function an investigation using a time series approach for an analysis of the relation of the EBA instrument with psychophysiological measures of work strain for a continuous workload assessment across complete shifts has recently been finished ${ }^{21}$ and will be used for adapting the criterion function where appropriate.

\section{Integrating economic aspects}

The implementation of the various time related cost functions now allows for a calculation of the costs associated with different shift schedules and with different solutions for a given scheduling problem. These differences usually arise from a different design of the shifts, e.g. with regard to their start and end times and the manning of the demands for workforce, resulting in different surcharges and allowances, whereas the sequence of shifts, i.e. the kind of rotation, seems to be of less importance. This of course will have to be further tested in the future. It would, however, be consistent with the observation that management generally does not care for or object to specific kinds of rotations in shift systems, their main concern usually is that the system works and that it does so at a low level of costs. The results gained with the new module so far support the hypothesis that from an economic point of view it does not make much of a difference whether a shift system is rotated slowly backward or fast forward.

As an example Figure 3 shows the results of the economic evaluation of two different solutions for a given problem of continuous shift work, one slowly backward rotated and the other one fast forward rotated. The ergonomic evaluation for both systems shows a lot of violations of the ergonomic criteria (indicated by the number and the kind of symbols in the shift schedules in Figure 3) for the slowly backward rotated system as opposed to only a few violations in the fast forward rotated system. However, the comparison of the economic costs (in $€$, or any other currency) for both solutions shows remarkable differences only in the costs for each individual shift group per week, within and between schedules. Since the groups are rotating in a four weeks cycle these differences balance out over a complete shift cycle in both systems, resulting in an indifference of total cost for both systems. These results clearly demonstrate that better shift rotas need not necessarily be associated with higher total costs, which is of importance in illustrating and supporting the ergonomic design of shift schedules from an economic point of view.

Going just one step beyond the results presented in Figure 3, one could assume that according to collective agreements surcharges need to be paid for weekly overtime (e.g. for more than 50 hours a week in this example). That would result in higher costs for the slowly backward rotated system (as presented in Figure 3 ) and in unchanged costs for the fast forward rotated system; even for a four week cycle. While the maximum of hours per week in the latter system is 50 hours (for group 1; see Figure 3, i.e. 6 × 8 hours +2 


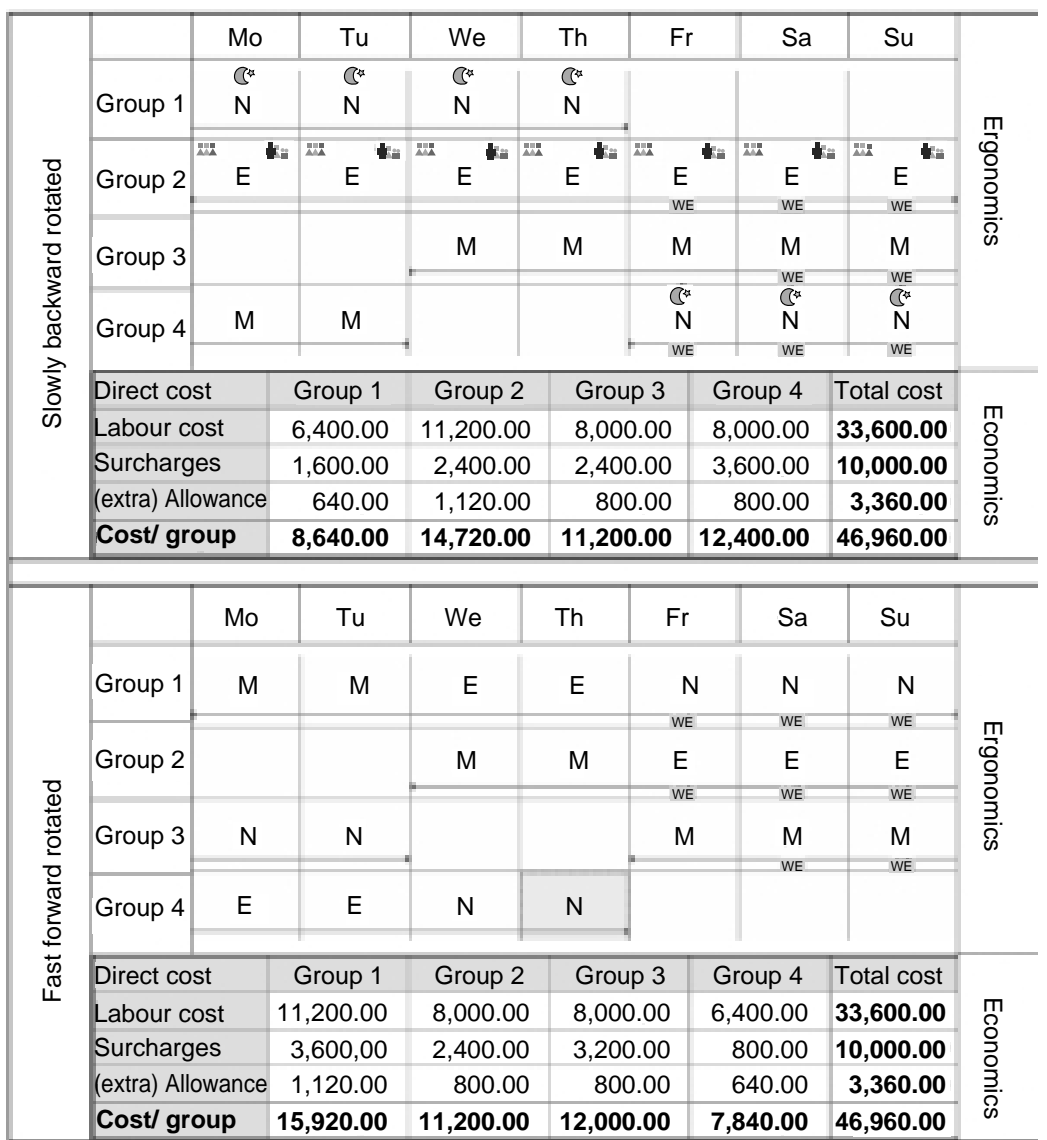

Figure 3 - Comparison of an ergonomically unfavorable shift schedule (slowly backward rotated, above) and preferable shift schedule (fast forward rotated, below) based on economic criteria (costs, surcharges, allowances; in • , or any other currency) [symbols in shift schedules indicate violations of ergonomic criteria].

hours on Sunday), it is 56 hours (group 2; see Figure 3 , with $7 \times 8$ hours) for the slowly backward rotated system, making these surcharges applicable and thus resulting in higher total costs. Assuming non-linear increasing surcharges beyond the legal permissible $48 \mathrm{~h}$ per week would lead to even greater differentials for both solutions. The sensitivity of the implemented functions thus definitely needs further testing.

Using the implemented cost functions now allows for the evaluation of the detailed and total costs of a system, but more important, also of the costs associated with any changes: it thus allows evaluating the costs associated with improvements regarding other criteria, which is always an important question when designing working hours according to ergonomic criteria. Another important step forward is that these functions can now be used in generating shifts and rotas, so that both ergonomic and economic criteria can be used for an optimization, showing the interdependencies in the results.

It should be noted, however, that the cost calculations at the moment do not take into account over- head costs, e.g. for maintenance, repairs, and services, and do not consider any effects of a bad shift design, e.g. compensating for health effects or effects regarding the risk of errors or accidents. This, of course, would probably change the balance considerably, e.g. by implementing surcharges for more than three night shifts in a row. Since such costs are difficult to estimate and to specify they have been left aside for the time being. However, the system in general would be open for such improvements. And it would seem most interesting to try and add a macroeconomic perspective to the business management perspective adopted here for the moment.

\section{DISCUSSION}

Computer aided design and evaluation of shift schedules should rather be regarded as a tool for supporting the designer than as an instrument for replacing her/his creativity, experience and professional qualification. This is especially true for the new aspects implemented in the programme BASS 4, because the more care is taken when assessing the job based workload or specifying of the relevant economic costs, the better the criteria will work and the better they will support the evaluation, generation, and optimization of shift schedules. According to the results for the integration of workload aspects the new EBA instrument seems to be a suitable and usable screening instrument for the intensity of workload and its temporal distribution for both ergonomics and job experts respectively. The concept of criterion functions, including the integration of job based and time based workload aspects, seems to be appropriate for an implementation into computer aided design and evaluation of shift schedules. However, further investigations, tests and adaptations will be necessary to improve the performance of the system. The new economics module allows for the assessment of the economic costs for a given or for alternative solutions for the design of a working time system and thus for the evaluation of the costs of (changes in) ergonomic criteria in the design of working time systems. This could be very helpful in convincing management that improvements in ergonomic design quality are not necessarily related to increased costs, but should, 
in the long run, result in economic benefits by avoiding the resulting costs of badly designed systems.

Integrating workload and economic aspects as criteria into computer aided design and evaluation of shift schedules can thus serve as a preventive strategy for improving workers' health and safety as well as the reliability and productivity of the work system. A fully operational version of BASS 4 (in German) will be available by the end of 2004 .

\section{REFEREN CES}

1. A kerstedt T. Work injuries and time of day - national data. Shiftwork Int Newsl 1995:12:2.

2. Andorre $V, Q$ uéinnec $Y$. Changes in supervisory activity of a continuous process during night and day shifts. Int J Ind Ergon 1998;21:179-86.

3. Andorre-Gruet $V$, Q uéinnec $Y$, Concordet $D$. Threeprocess model of supervisory activity over 24 hours Scand J Work Environ Health 1998;24(Suppl 3):121-7.

4. Bartenwerfer $H$, Kötter L, Sickel W. Beiträge zum Problem der psychischen Beanspruchung - II. Teil Verfahren zur graduellen Beurteilung der psychischen Beanspruchung in der Industrie. Köln: Westdeutscher Verlag; 1963. (Forschungsberichte des Landes NRW, Band 141, Hefte 1131).

5. Bea FX, Dichtl E, Schweitzer M. Allgemeine Betriebswirtschaftslehre. Grundfragen. Stuttgart Lucius \& Lucius; 2000. Band 1.

6. Bea FX, Dichtl E, Schweitzer M. Allgemeine Betriebswirtschaftslehre. Leistungsprozess. Stuttgart: Lucius \& Lucius; 2002. Band 3.

7. Beermann B. Leitfaden zur Einführung und Gestaltung von Nacht- und Schichtarbeit. Dortmund: BAuA; 2001.

8. Bourdouxhe $M, Q$ uéinnec $Y$, Guertin $S$. The interaction between work schedules and workload: Case study of 12-hour shifts in a Canadian refinery. In Hornberger S, Knauth P, Costa G, Folkard S, editors. Shiftwork in the $21^{\text {st }}$ century: challenges for research and practice. Frankfurt: Peter Lang; 2000. p. 61-6.

9. Brathe $B, Q$ uéinnec $Y$, Verdier $F$. L'analyse de l'activité de travail en postes de nuit: Bilan de 25 ans de recherches et perspectives. Trav Hum 2004;67:41 61.

10. Craig A, Baer K, Diekmann A. The effects of lunch on sensory-perceptual functioning in man. Int Arch Occup Environ Health 1981;49:105-14.

11. Eilers $\mathrm{K}, \mathrm{N}$ achreiner $\mathrm{F}$. Time of day effects in vigilance performance at simultaneous and successive discrimination tasks. In: Costa G, Cesana G, Kogi K, Wedderburn A, editors. Shift work, health, sleep and performance. Frankfurt: Peter Lang; 1990. p. 467-72.

12. Folkard S. Effects on performance efficiency. In: Colquhoun WP, Costa G, Fokard S, editor. Shiftwork: problems and solutions. Frankfurt: Peter Lang; 1996. p. $178-83$.
13. Folkard S, Åkerstedt T, M acdonald I, Tucker P, Spencer M. Refinement of the three-process model of alertness to account for trends in accident risk. In: Hornberger S, Knauth P, Costa G, Folkard S, editors. Shiftwork in the $21^{\text {st }}$ century: challenges for research and practice. Frankfurt: Peter Lang; 2000. p. 49-54

14. Frieling $\mathrm{E}, \mathrm{H}$ oyos $\mathrm{C}$. Fragebogen zur Arbeitsanalyse. Bern: Huber; 1978. [FAA; German version of the Position Analysis Q uestionnaire - PAQ ].

15. Gärtner J, Hörwein $K$, Janke $M, W$ ahl $S$. Schichtplanassistent 3.0 - Flexible Werkzeuge für die Schichtplangestaltung. Angew Arbeitswiss 1998;157:27-45

16. Graf $O$. Über lohnendste Arbeitspausen bei geistiger Arbeit. In: Kraepelin E, editor. Psychologische Arbeiten. Berlin: Springer; 1922. v. 7. p. 548-611.

17. Grzech-Šukalo $H$, Hänecke $K$, Jäger $C, N$ achreiner F. Positive Gestaltungsbeispiele der DV-gestützen Schichtplangestaltung. D ortmund: BAuA; 2001.

18. Hänecke K, Tiedemann S, Nachreiner F, GrzechŠkalo $H$. Accident risk as a function of hours at work and time of day as determined from accident data and exposure models for the German working population. Scand J Work Environ Health 1998;24(Suppl 3):43-8.

19. ISO 10075. Ergonomic principles related to mental work-load. General terms and definitions. Geneva: ISO ; 1991.

20. ISO 10075-3. Ergonomic principles related to mental work-load. Part 3: Measurement and assessment of mental work-load. Geneva: ISO; 2004

21. Klostermann A. Zur Evaluation von Arbeitsanalyseverfahren anhand des "Verfahrens zur Einschätzung der Belastung am Arbeitsplatz (EBA)" [Diplomarbeit]. Oldenburg: Carl von O ssietzky Universität; 2004.

22. Knauth P. Computergestützte Gestaltung diskontinuierlicher Schichtpläne nach arbeitswissenschaftlichen Kriterien. $Z$ Arbeitswiss 1987;41:224-6

23. Nachreiner F. Eigenzustandsskalierung zur Integration von Beanspruchungen. In: Rohmert $W$, editor. Ergonomie kombinierter Belastungen. Köln: Schmidt; 1982. p. 47-57. 
24. Nachreiner F. Ergonomics and standardization. In: Stellman JM, editor. Encyclopaedia of O ccupational Health and Safety. Geneva: ILO; 1998. v. 1. p. 29.11-4.

25. Nachreiner F. Time on task effects on safety. J Hum Ergol (Tokyo) 2001;30:97-102.

26. Nachreiner F. Arbeitszeit und Unfallrisiko. In: Trimpop R, Zimolong $B$, Kalveram $A$, editors. Psychologie der Arbeitssicherheit und Gesundheit. Neue W elten Alte Welten. Heidelberg: Asanger; 2002. p. 5-21.

27. Nachreiner F, Q in L, Grzech-Šukalo H, Hedden I. Computer-aided design of shift schedules. Ergonomics 1993;36:77-83.

28. Nachreiner F, Grzech-Šukalo H, Hänecke K, Q in L, Dieckmann P, Eden J, Lochmann R. Arbeitszeit ergonomisch gestalten. Eine Software zur Erstellung von Schichtplänen. Bremerhaven: W irtschaftsverlag NW; 1999

29. Nachreiner F, Akkermann S, Hänecke K. Fatal accident risk as a function of hours into work. In Hornberger S, Knauth P, Costa G, Folkard S, editors. Shiftwork in the $21^{\text {st }}$ century: challenges for research and practice. Frankfurt: Peter Lang; 2000. p. 19-24.

30. Nachreiner F, Grzech-Šukalo H, Möhlmann D, Nickel P, Trauernicht K. Beteiligungsorientierte und sozialverträgliche Arbeitszeit- und Pausengestaltung im Stadt- und Regionalverkehr (SuRV). Berlin: Rev. di Bundesvorstand; 2003.

31. Pohlandt A, Schulze F. Handbuch mit PC-Programm REBA-AS. Rechnergestütztes Dialogverfahren für die Bewertung und Gestaltung von Arbeitstätigkeiten unter Berücksichtigung von Sicherheit und Gesundheitsschutz. Bochum Technik \& Information; 2001.

32. Rogers AS, Spencer MB, Stone BM. Validation and development of a method for assessing the risks arising from mental fatigue. Sheffield: HSE Books; 1999.

33. Rohmert W, Landau K. Das arbeitswissenschaftliche Erhebungsverfahren zur Tätigkeitsanalyse (AET). Bern: Huber; 1979.

34. Rutenfranz J, Knauth $P$, Nachreiner $F$ Arbeitszeitgestaltung. In: Schmidtke $\mathrm{H}$, editor. Ergonomie. München: Hanser; 1993. p. 574-99.
35. Schmidt KH, Kleinbeck U, Ottmann W, Seidel B. Ein Verfahren zur Diagnose von Arbeitsinhalten: Der Job Diagnostic Survey (JDS). Z Arbeits O rganisationspsychol 1985;29:162-72.

36. Schmidtke H. Mentale Beanspruchung durch informatorische Belastung. In: Schmidtke $\mathrm{H}$, editor. Ergonomie. München: Hanser; 1993. p. 143-60.

37. Schönfelder E, Knauth P. A procedure to assess shift systems based on ergonomic criteria. Ergonomics 1993;36:65-76.

38. Schomann C, Pankonin C, Nachreiner F. Computer Aided design of working hours - integrating workload aspects and scheduling flexible work hours. Shiftwork Int Newsl 2001;18:158.

39. Schomann C, Stapel W, Nickel P, Meyer I, Janßen D, Eden J et al. Arbeitszeit ergonomisch gestalten Entwicklung einer Software zur Evaluation und Gestaltung von Arbeitszeitsystemen. In: Zülch G Stock $P$, editors. Arbeitszeitsysteme im Dienstleistungsbereich und ihre Einführung. Karlsruhe: ifab; 2003. p. 43-54.

40. Schomann C, Klostermann A, Nickel P, Nachreiner $F$ Ergonomic design of working hours - integrating workload aspects. Shiftwork Int Newsl 2003;20:170.

41. Schomann C, Stapel W, Nickel P, Eden J, Nachreiner F. Arbeitszeit ergonomisch gestalten - Ein Softwaresystem zur Evaluation und Gestaltung von Arbeitszeitsystemen. In: Gesellschaft für Arbeitswissenschaft EV, editor. Arbeit + Gesundheit in effizienten Arbeitssystemen. Dortmund: GfA-Press; 2004. p. $275-8$.

42. Wahl S, Muslija N, Angelova R, Slany W, Fingerlos R, Herber $G$ et al. Shift-Plan-Assistant: SPA 4.0 - State of development. In: Hornberger S, Knauth P, Costa G, Folkard S, editors. Shiftwork in the $21^{\text {st }}$ century: challenges for research and practice. Frankfurt: Peter Lang; 2000. p. 327-32.

43. Wedderburn A. Guidelines for shiftworkers. Eur Found Bull Eur Shiftwork Topics 1991;Suppl 3:11-6.

44. Winer BJ, Brown DR, Kenneth MM. Statistical principles in experimental design. New York: McGraw-Hill; 1991 